\title{
FORMS OF SUBGLACIAL EROSION ON PALAEOZOIC SEDIMENTARY ROCKS
}

\author{
(Abstract only) \\ by \\ R. J. Rogerson and R. Kodybka \\ (Department of Geography, Memorial University of Newfoundland, St. John's, \\ Newfoundland A1B 3X9, Canada)
}

\section{ABSTRACT}

The relationship between bedrock erodibil$i$ ty and the characteristic bed form and roughness produced by subglacial abrasion is largely unknown. Less resistant bedrocks may be abraded down to a surface of low obstacle size and low roughness parameter. However, Hallet (1979) notes that bedforms are probably dampened at widely varying rates, and that certain bedforms may actually be amplified through time by rapid trough abrasion. The object of this paper is to examine the relationship between the mechanical strength of several bedrock types and the magnitude of subglacially streamlined bed forms found on them.

Cambrian limestones, mudstones, dolomites, and chert, some with abundant quartz veins, are the bedrock types examined. They lie as a series of steeply-dipping beds up to $100 \mathrm{~m}$ thick with their strike across the floor of the Yoho valley, in the Rocky Mountains of British Columbia. They were covered by the ice of Yoho Glacier 30 years ago, and are now less than $0.5 \mathrm{~km}$ below the present ice terminus. The sites examined lie within an area less than
$0.25 \mathrm{~km}^{2}$, up-glacier from a major riegel form. The Yoho River nearby flows in a deep gorge and has not affected this section of the former glacial valley floor.

The bedrocks were analysed and tested in the laboratory for mechanical strength and resistance to abrasion.

During summer 1979, streamlined bedforms and surface roughness were surveyed along the former glacier flowl ine, evidenced by striations, and plane table maps were completed across several beds. Small $1 \mathrm{~m}^{2}$ plots were surveyed in detail on each bedrock type. Analys is of surface forms has included 3-dimensional SYMVU plots. Preliminary indications are that the micro-roughness shows greater variability between bedrock types than do large wavelengths of relief. However, resistant bedrocks are areas of prominent positive relief while others are generally low-lying. Analysis of the results continues.

\section{REFERENCE}

Hallet B 1979 A model of glacial abrasion. Joumal of Glaciology 23(89): 39-50 